\title{
ОСОБЛИВОСТІ СУФІКСАЛЬНОГО СЛОВОТВОРЕННЯ НЕОЛОГІЗМІВ НА ПОЗНАЧЕННЯ ОСІБ У СУЧАСНІЙ УКРАЇНСЬКІЙ МОВІ
}

У статті проведено аналіз одного з важливих шарів поповнення тексичної системи української мови початку ХХІ століття - неологізмів на позначення осіб. Різнобічно схарактеризовано словотвірні особливості суфіксальних дериватів (переважно загальномовних і частково індивідуально-авторських). Детально розглянуто продуктивні й малопродуктивні суфікси та субіксоїди в иих процесах. Відзначено зростання продуктивності творення неологізмів-фемінативів: як таких, що поступово набувають статусу загальновживаних та стають нормативними, так і розмовних некодифікованих.

Ключові слова: словотворення, деривачія, назви осіб, субікс, суфіксоїд, неологізм, фемінатив, формант.

Styshov O. Peculiarities of Suffixal Word Formation of the Neologisms Denoting Identification of Persons in Modern Ukrainian Language. In the paper the author analyzes the suffixal word formation of one of the important layers of the lexical system of the Ukrainian language at the beginning of the XXI century, namely the neologisms denoting persons. Despite the constant interest of Ukrainian and foreign scholars in this issue, it nonetheless requires constant and thorough consideration within the framework of modern Ukrainian language characteristics. We consider this issue as a topical one since the corpus of these innovative units represents a dynamic subsystem that is constantly enriched and modified, and thus insufficiently studied in terms of its word formation potential. The aim of the paper is to perform a comprehensive analysis of the word forming features of suffixal neologisms that denote persons (mainly colloquial and partially idiolectal) in the Ukrainian language at the beginning of the XXI century. The objectives of the paper are as follows: 1) to introduce into scientific usage a number of neologisms which are both of linguistic and purely practical, especially lexicographic, interest; 2) to identify productive and unproductive suffixes and suffixoids involved in the formation of neologisms denoting persons. The paper thoroughly considers and characterizes word-forming features of the studied derivatives with a special attention given to productive and unproductive suffixes and suffixoids that participate in these derivational processes. It has been found out that there is an increase in the productivity of the formation of new feminine lexical units. These units are both of general usage, i.e. those that gradually acquire the status of common lexical units and become the normative ones, and of colloquial usage, mostly non-codified and derived by such productive suffixes as: 
$-k(a)-,-i n(y a),-i t z(y a)-$. The neologisms that denote males are created with the help of such productive suffixes as -ik, -ach, -ets/-ivets, -ist/-ist, -ator, -ar and such suffixoids as -lyub, -man, -fil, -fob. As a result of the study the author came to the conclusion that the category of names of persons in Ukrainian language as of the beginning of the XXI century, as well as its lexical system in general, is dynamically developing and is intensively replenished with new words. The paper ascertains that among the main sources of innovation and enrichment of the Ukrainian language, the suffixal word formation has been and still remains the most productive one. Feminine nouns formation is registered as the most active one. In the future, it is necessary to further explore other ways of these nouns formation as well as define the main trends in these processes in both Ukrainian and modern Slavic languages.

Key words: word-formation, derivation, names of persons, suffix, suffixoid, neologism, feminative, formant.

\section{Вступ}

В останні десятиліття лексико-семантична система української мови характеризується стрімкою динамікою розвитку. У цьому процесі провідну роль відіграють лексичні й семантичні неологізми, інтенсивність виникнення яких нині можна сміливо назвати «бумом інновацій». Дослідженню таких одиниць у кінці XX - на початку XXI ст. приділяли й приділяють увагу ряд українських (О. Муромцева, Н. Клименко, О. Тараненко, К. Городенська, Є. Карпіловська, А. Архангельська, О. Семенюк, Л. Струганець, А. Нелюба, Ж. Колоїз, Г. Вокальчук, М. Навальна, Л. Кислюк, Г. Віняр, О. Тодор, Д. Мазурик, Т. Коць, С. Лук'яненко, Т. Стасюк, С. Зайцева, А. Таран, Л. Туровська, М. Бойчук, Т. Панченко, К. Ленець та ін.) і зарубіжних (В. Костомаров, О. Земська, О. Розен, Л. Ферм, О. Дуліченко, Е. Галлоєва, С. Алаторцева, О. Лукашанець, К. Вашакова, Ц. Аврамова, О. Мартінцова, К. Вачкова, Г. Ядацька, С. Гайда, Ю. Фурдік, К. Гутшмідт, Г. Шмідт, Д. Герберг, Р. Берчфільд та ін.) лінгвістів. Проте, на нашу думку, на сьогодні мало уваги приділено комплексному студіюванню особливостей словотворення нових назв осіб. Поки що засвідчено незначну кількість робіт, присвячених цій проблематиці в слов'янських мовах (Архангельська, 2019; Ніколаєнко, 1999; Буднікова, 2007; Вишневська, 2001; Нелюба, 2011: 137-142, Нелюба, 2011: 49-59; Навальна, 2008, Навальна, 2011; Сидоренко, 2000; Годована, 2007 та ін.). Названа проблема в сучасній українській мові вимагає постійного й скрупульозного вивчення, оскільки кількісний і якісний шар нових номінацій названої категорії 
постійно зростає. Тому це й визначає актуальність теми нашої статті як в україністиці, так і в лінгвістиці загалом.

Мета роботи - комплексно проаналізувати словотвірні особливості суфіксальних неологізмів на позначення осіб (переважно загальномовних і частково індивідуально-авторських) в українській мові початку XXI століття.

Основні завдання статті: 1) увести до наукового обігу певний корпус неологізмів, що становлять як лінгвістичний інтерес, так і суто практичний, особливо лексикографічний; 2) виявити продуктивні та малопродуктивні суфікси й суфіксоїди в процесі творення неологізмів на позначення осіб.

Матеріалом для статті слугували численні субстантивні новотвори на позначення осіб (понад 1500 одиниць), зафіксовані в сучасній публіцистиці (програмах і передачах радіо й телебачення, газетах, журналах), красному письменстві та інтернет-дискурсі, що охоплюють значний часовий проміжок, зокрема 2000-2020 роки.

\section{Методи дослідження}

Методи дослідження зумовлені специфікою вивчення матеріалу й метою його студіювання. Аналіз досліджуваних одиниць проведено за допомогою загальнонаукових методів - аналізу, синтезу, індукиї, дедукції. Використано ряд лінгвістичних методів, зокрема такі: описовий для виокремлення нової української лексики й термінології на позначення осіб, їх систематизації та аналізу; словотвірний аналіз застосовано під час дослідження дериваційних особливостей лексем на позначення осіб; компонентний аналіз, який дав змогу вивчити лексичну семантику зазначених одиниць, установити лексико-семантичні відношення; порівняльний метод, що сприяв осмисленню змін лексико-семантичної структури слова; дистрибутивний аналіз із метою дослідження названих одиниць мови на основі оточення (розподілу) в тексті, а також частково була використана методика кількісних підрахунків.

\section{Виклад основного матеріалу}

Засвідчене зібраним фактичним матеріалом інтенсивне збільшення різноманітних неологізмів на позначення осіб $є$ незаперечним доказом посилення тенденції до антропоцентризму в українській мові початку XXI ст. Безперечно, цьому сприяла низка факторів як екстра-, 
так й інтралінгвального характеру, задіяних переважно комплексно, у взаємопереплетенні. Незаперечним є факт, що позамовні чинники сприяли динамічному творенню нових слів аналізованої групи, що зумовлено постійною потребою номінації (звичайно, прагматичного характеру) осіб, зокрема за певним видом занять і захоплень, за належністю до соціальної групи, організації, об’єднання і т. ін. чи якоюсь іншою специфічною особливістю, ознакою. Внутрішньомовні ж чинники не перешкоджають входженню зазначених новотворів до лексичної системи мови, оскільки процес деривації відбувається переважно за наявними в українській мові словотвірними типами й моделями.

Зібраний і проаналізований значний корпус фактичного матеріалу доводить, що традиційно для української мови високою словотворчою продуктивністю характеризується морфологічний спосіб деривації, який істотно домінує над іншими способами. У межах останнього значно переважає суфіксація, тобто продукування нових іменників на позначення осіб за допомогою питомих і запозичених суфіксів та суфіксоїдів.

Цікаво, що в останні десятиліття в національному словотворі помічено значну активізацію процесу фемінізації (моції). Фемінативи підсистема морфологічних одиниць, чітко окреслених граматичним жіночим родом, альтернативні або парні аналогічним поняттям чоловічого роду. Інтенсифікацію творення й уживання таких одиниць спричинено рядом факторів: значно ширшим опануванням жінками суто «чоловічих» царин діяльності, а також зростанням в українському соціумі під впливом Заходу ідей фемінізму, спрямованих, зокрема, і на подолання «мовної дискримінації жінки» (Тараненко, 2015: 69). Це засвідчено як солідним шаром дібраних ілюстрацій, так і науковим доробком українських учених (див. праці Тараненко, 2005: 3-25; Тараненко, 2015: 68-70; Архангельська, 2019; Нелюба, 2011: 49-59; Кислюк, 2013: 114-118; Кислюк, 2017 та ін.).

Швидке й постійне оновлення корпусу фемінної лексики та термінології переконливо відбиває динаміку суспільно-політичного, соціально-економічного, наукового, технічного, побутового, ментально-когнітивного розвитку як української, так і світової спільноти.

Дібраний нами корпус фактажу переконливо доводить, що в сучасній українській мові найбільш продуктивним у деривації фемінативів виступає суфікс -к(a). Помічено, що він приєднується 
переважно як до відомих (анімалістка, банкірка, лідерка, менеджерка, канилерка, програмістка, офічерка, режисерка), так і до нових запозичених твірних основ на позначення чоловічих професій або маскулінних номенів подвійного роду й назв різних видів діяльності (бутзалістка, баристка, грумерка, акваболістка, дайверка, блогерка, тічерка). Дещо рідше аналізований афікс сполучається з питомими мотиваторами (керманичка, богатирка, велетка). Варто акцентувати, що більшість таких одиниць мають відчутний відтінок розмовності (нобелістка, сталкерка, піаристка, бодибілдерка, геймерка, євродепутатка), а іноді й неприродності, штучності (старостка, європка, геройка). Напр.: Офічерка Збройних сил Украйни Тетяна Науменко вже понад рік у зоні бойових дій виховує донечку - півторарічну Софійку ${ }^{1}$; Білицькі футзалістки з рахунком 4:2 перемогли «Сулу» з Лубенського районуг; І Інтернет підкорила поштарка, яка випадково зіпсувала блогеркам відеоз; Словник МВС: в Україні з'явилися рятівниия, пожежниця та прес-офіцерка ; Також нас [учасників волонтерської акції «Свята без тата»] підтримала цьогорічна нобелістка Ольга Токарчук та чемпіонка Європи з боксу Олександра Сидоренко незначна частина таких утворень набула ознак нормативності й кодифікованості: новелістка, футболістка, боксерка, номінантка та ін. Пор.: Дід актриси по батькові, Клод Кокберн, був британським романістом і журналістом, а ї тітка Сара Кодвелл - відома британська новелістка, автор безлічі детективних романів (А. Кокотюха); Серед представників Національної збірної Украйни - ковельчанка, найтитулованіша боксерка, дванадиятиразова чемпіонка України, чемпіонка Європи, бронзова призерка чемпіонату світу з боксу Тетяна Кобб.

1 Трощук С. Офіцерка ЗСУ Тетяна Науменко виховує в зоні ООС донечку. Zaxid.net.

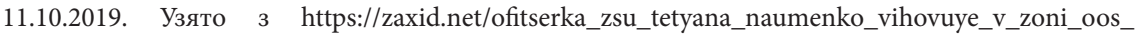
donechku_n1490850.

2 Сабіров Р. Кобеляцькі й білицькі футзалістки виходять у фінал. Тижневик ЕХО. 09.11.2017. Узято з https://exo.in.ua/news/38768.

3 Інтернет підкорила поштарка, яка випадково зіпсувала блогеркам відео. Padio Люкс. 07.05.2020. Узято $3 \mathrm{https://lux.fm/merezhu-pidkorila-poshtarka-yaka-vipadkovo-zipsuvala-}$ blogerkam-video_n94565.

4 Etcetera: интернет-газета. Узято з http://uk.etcetera.media/ - заголовок статті.

5 «Свята без тата»: волонтери з Європи, Америки та Австралії доставили іменні подарунки для дітей наших захисників. Міністерство оборони України. Узято з https://www.mil. gov.ua/special/news.html?article $=55021$.

6 Ковельчанка Тетяна Коб здобула дебютну перемогу на Європейському ліцензійному турнірі у Лондоні. КОВЕЛЬ РОST. 15.03.2020. Узято з https://kovelpost.com/news/7150?fbclid=IwA R2qFbywhMMHulXKGMhP-LavUZivZHkyMHQvDJvHko0UzxibhKM-ckZyuKw. 
Також у досліджуваний період у національній мові засвідчено тенденцію до наростання словотвірної активності непродуктивного в радянську добу питомого суфікса -ин(я), що поєднується з іменниковими твірними основами. Цей афікс сприяє збагаченню корпусу фемінативів, утворюючи їх за питомою та здавна відомою словотвірною моделлю - іменникова твірна основа (переважно слова чоловічого роду) + суфікс -ин(я), яка походить ще зі спільнослов'янської мови і яка нині відродилася. На нашу думку, у процесі деривації нових назв жінок важливу роль також відіграє аналогія: саєнтологиня, політологиня, гравчиня та ін. (порівняй: грекиня, берегиня, кравчиня). Важливо, що утворені за допомогою аналізованого суфікса деякі слова поступово витісняють російські входження радянської доби (пор.: плавчиня (зам. плавчиха), продавчиня (зам. продавщиия). Поки що переважна більшість таких утворень містять відтінок розмовності: видавчиня, ворогиня, синоптикиня, політикиня, виборчиня, творчиня, археологиня, біологиня та ін. Окремі з аналізованих витворів $є$ дещо недолугими, а тому не сприймаються значною частиною мовців: лижиня (зам. тижниия), анатоминя (зам. жінка-анатом), теоретикиня (зам. жінка-теоретик), курчиня (зам. жінка-курець). Уважаємо, що їх не варто кодифікувати. Хоча вже маємо приклади, коли в процесі активного функціонування, інтенсивного «розкручування» (особливо в дискурсі мас-медіа), деякі з них поступово втратили маркер розмовності й набули статусу нейтральних (мисткиня, плавчиня, борчиня, членкиня, ковалькиня 'жінка-коваль'), проникнувши в усі функціональні різновиди сучасної української мови. Названі вище одиниці переконливе підтвердження вияву тенденції до автохтонізації, тобто прагнення до повернення національної ідентичності й самобутності українській мові. Серед аналізованих утворень засвідчено одиниці, що виникли завдяки певній стилістичній настанові авторів: совкиня, олігархиня, білологиня та ін. Вони характеризуються переважно негативнооцінною маркованістю, спрямованою на викриття, розвінчання, осуд, несприйняття та ін. кого-небудь: Майже кожному з нас доводилося чути звинувачення когось у совковій ментальності: «Ти совок (або ж совкиня)!». За иим, зазвичай, ідуть і докази совковості ... (газ. «Україна молода», 01.07.2015.); Олігархині тисячі євро викидають на таке, а наші красуні на «зеленому» морі задурно перетворюються на мулаток-шоколадок'.

Дати 6 моделі город і корову! Вільне життя. 02.07.2016. Узято з http://vilne.org. ua/2016/07/daty-b-modeli-gorod-i-korovu/. 
На початку XXI століття в українській мові помічаємо істотне зростання продуктивності словотвірної моделі, коли до твірних основмаскулізмів додається питомий суфікс -uи(я). У результаті інтенсивно продукуються одиниці на позначення осіб жіночої статі за родом діяльності, професією, тобто переважно агентивів: віриувальниия, очільниия, програмувальниия, айтішниия, доброволиия, барабанниия, валютниия, інтернетниия, оскаржниия та ін. Пор.: Середня інтернетниия проводить в Інтернеті понад 40 годин у місяиь ${ }^{8}$; Очільниия МВФ: Світова економіка вже увійшла в рецесію (заголовок статті) (газ. «День», 27.03.2020.). Засвідчено також похідні утворення за іншими особливостями: чарівливиия, одержимиия, довічниия ('жінка, засуджена до довічного позбавлення волі'), оскароносиия та ін. Напр.: Пройшли роки, і маленька пустунка, весела чарівливиия, добре дівча перетворилося на чудову фею ; - Ось вона, наша українська Надія [Крутова-Шестак]! Чарівливиия, чию пісню знають і люблять не лише в Україні, а й за межами нашої держави. Вона прославляє нашу землю (газ. «Столиця», 20.12.2005.); Біля Качанівської колонії, щцо на Харківщинні, довічницю зустрічали з квітами друзі, адвокат Андрій Федур, нардеп від БПП Олександр Грановський, який несподівано перейнявся долею довічнииі (газ. «Високий замок», 11.04.2018.). Як і в наведених вище фемінативах, в аналізованих утвореннях також відчутним $\epsilon$ відтінок розмовності: одержимиия, катівниия, принадниия, позувальниия та ін., пор.: 3 иієї обвішаної «маузерами», «кольтами», «наганами» принаднииі Лариси драматург Всеволод Вишневський зліпив образ головної героїні у n'єсі “Оптимістична трагедія» ${ }^{10}$. Окремі одиниці проникли в розмовне мовлення із жаргонів: ватниия ('малоосвічена, люмпенізована і здебільшого проросійськи налаштована особа, чия соціально-політична позиція суттєво спотворена внаслідок перманентного впливу російської пропаганди'); прикидниия ('жінка, яка відзначається прикидом, тобто вбранням'): Як «ватниия» за 30 гривень збирає «безкоштовні» мітинги бюджетників (ФОТОФАКТ) $)^{11}$.

8 Затварницька-Мадура Б. Зразки споживацької поведінки жінок у Польщі. Узято 3 http://vlp.com.ua/files/special/44.pdf.

9 Facebook. Узято з https://www.facebook.com/.

10 Багацький Л. Найвідоміший плейбой Кіровоградщини. Zlatopil. 02.01.2016. Узято 3 https://zlatopil.com/life/8668-naividomishyipleiboikirovohradshchyny.

11 Як «ватниця» за 30 гривень збирає «безкоштовні» мітинги бюджетників (ФОТОФАКТ). Есnресо. 26.12.2014. Узято 3 https://espreso.tv/news/2014/12/26/yak_quotvatnycyaquot_ za_30_hryven_zbyraye_quotbezkoshtovniquot_mitynhy_byudzhetnykivfotofakt. 
Відомий український лінгвіст О. О. Тараненко слушно зауважує на переважному функціонуванні наведених вище фемінативів у 3MI, перекладній літературі, кінопродукції (як і раніше - у розмовній мові), водночас як в офіційно-діловому та науковому стилі переважають форми чоловічого роду (із вказівкою в разі потреби на стать) (Тараненко, 2005).

Творення назв осіб чоловічої статі в українській мові початку XXI ст. найбільш інтенсивно відбувається за допомогою давніх слов'янських і питомих українських суфіксів, які приєднуються як із відомими, так і новозапозиченими твірними словами-основами: - $\boldsymbol{u \kappa}$ (адекватник, дистаниійник, кальянник, однофракційник, епатажник, тестувальник), -ач (продукувач, примирювач, покращувач, виголошувач, зливач 'той, хто бореться за злиття націй і культур', додзвонювач, домукувач), -ець--івець (піарівець, інтернетівець, майданівець, мітинговець, виступовецьь). Пор. у контекстах: Дистанційники ж можуть вільно спілкуватися з викладачем у будь-який час та отримати повний об'єм матеріалів ${ }^{12}$; Для шанувальників східних традицій кальянник запропонує кальян ${ }^{13}$; Меркель у важкій ролі примирювача Росії та України («Радіо Свобода», 27.08.2014. - заголовок); У Тернополі під час «Братерської ходи» об'єдналися волонтери, майданівиі і бійцъі (газ. «День», 23.08.2015.). Тобто ці постпозитивні форманти нині відзначаються високою продуктивністю. Характерно, що останній з названих суфіксів активно поєднується з мотиваційними основами на позначення партій, блоків, рухів, фракцій, різних організацій та ін. (опоблоківець, ударівець, БЮТівець / б’ютівець, свободівеи, хамасівець, ідилівец, радівець, атовець, вагнерівець), а також назв відомих і впливових осіб сьогодення (зеленівець, трампівець, путінець, лукашенківещь). Напр.: А якщцо серйозно, то опоблоківців вкотре підвела провідна їхня риса - жадібність (газ. «День», 23.11.2018.); Головний «зеленівець» Обухівщини визнав, що дострокових виборів в Обухові не буде $e^{14}$. У сучасній українській мові за допомогою зазначених вище

12 Дистанційна освіта здійснюється лише в ХНУ. Bсім. 12.07.2007. Узято з https://vsim.ua/ Podii/distantsiyna-osvita-zdiysnyuetsya-lishe-v-hnu-68596.html.

13 Моноліт: туроператор. Узято 3 http://monolittour.lviv.ua/katalog_1/kaciveli_118/ solnechnaja_dolina_-_pansionat_86/1.

14 Головний «зеленівець» Обухівщини визнав, що дострокових виборів в Обухові не буде. Хроніки Обухова. 27.08.2019. Узято з https://obukhiv.info/news/golovnii-zelenivetc-obukhivshchiniviznav-shcho-dostrokovikh-viboriv-v-obukhovi-ne-bude/. 
афіксів спостерігаємо явище поступової активізації продукування пуризмів замість давніх невдалих або й нав'язаних запозичень і деяких нових іншомовних слів (переважно з російської мови й рідше - iз англійської), зумовлене тенденцією до автохтонізації (націоналізації): барабанник (зам. барабанщик), грабітник 'той, хто робить графіті' (зам. грабітчик), страусівник (зам. страусовод), хурмівник (зам. хурмовод), кактусівник (зам. кактусовод, кальянник (зам. кальянщик), паркурник (зам. паркурщик), дерибанник розм. (зам. дерибанщик), вимагач (зам. рекетир), розігрувач (зам. плеймейкер), зваблювач (зам. пікапер) та ін. Пор.: Марк Джуліана вважається одним із провідних барабанників сучасності ${ }^{15}$; За ним [Іваном Мазепою] $з$ юнацьких літ повелася слава зваблювача жіночих сердець ${ }^{16}$.

3-поміж продуктивних питомих суфіксоїдів виділяємо формант -люб, який сполучається із запозиченими та слов'янськими основами: пиволюб ('любитель пива'), жінколюб ('той, хто дуже любить жінок; бабій’), моволюб, словолюб, музиколюб, ігролюб та ін. Ілюструємо в контексті: Патрульні мають право перевірити вміст пакета. А також визначити на запах рідину, що у пляшиі без етикетки. Тому подібні хитрощі на наших правоохорониі не діють. А пиволюбам таки доведеться привести свої звички у відповідність до нових правил ${ }^{17}$; "Львів швидие у снігу» - читаємо в газеті, $і$ знову згадуються слова великого словолюба О. Кундзіча про «погублені дієзи нашої мови» (газ. «Кримська світдиия», 07.07.2006.); Шановні ігролюби, ось-ось у иутеpi RUINER буде українська мова ${ }^{18}$.

Серед малопродуктивних питомих суфіксів на позначення назв осіб варто назвати такі: -льник (бойкотувальник, кліпувальник, татуювальник), -ес(а) (агентеса, фотографеса), -ун (лайкун - 'той, хто ставить лайки, тобто схвалення користувачем інтернету матеріалу, профілю користувача, фотографії і т. ін. через клік чи натискання функціональної кнопки', крадун, їзднн - розм. 'невмілий водій'), -уга/-юга (піарюга, сепаратюга, егойстюга). Названі утворення

15 Барабанник, який співпрацював із Девідом Боуі, став найкращим у 2017-му. Громадське радіо. 23.02.2019. Узято з https://hromadske.radio/podcasts/jazztalks/barabannyk-yakyyspivpracyuvav-iz-devidom-boui-stav-naykrashchym-u-2017-mu.

16 Славутич Ю. Іван Мазепа - гетьман української долі. Волинь: рівненський обласний народний тижневик. Вип. 1311. Узято з http://volyn.rivne.com/ua/4884.

17 Пивомани під прицілом. Вікка. 18.05.2020. Узято з https://www.vikka.ua/novini-na-vikka/ vikka-novini/pivomani-pid-pricilom/.

18 Facebook. Узято 3 https://www.facebook.com/. 
вносять у контексти певний стильовий і стилістичний заряд (маркованість), зокрема негативнооцінного характеру: Поки щьо бажаної підтримки [в Білорусі] бойкотувальник [виборів Барис Хамайда] не дістав (ж-л «Укр. тиждень», 03.01.2014.); За легендою, приваблива агентеса Вікторія - ие наївна екс-модель, яка не має жодної освіти ${ }^{19}$; Роман Гізер Морріс «Татуювальник Аушвічу» очолив список бестселерів за версією The New York Times - ZAXID.NET ${ }^{20}$; Час від часу якийсь сепаратюга вставав і випускав у наш бік чергу з автомату, очікував декілька секунд відповіді і залягав в окоп ${ }^{21}$; Щойно ще один іздун спричинив ДТП в иентрі. Очевидиі кажуть, ио беха на ивидкості так влупила авто, яке пригальмовувало перед зеброю, шо воно аж вилетіло на тротуар до Оизадбанку $y^{22}$.

Зібраний фактичний матеріал засвідчив, що порівняно 3 питомими суфіксами в процесі творення назв осіб дещо меншою словотвірною активністю (проте продуктивні) в досліджуваний період відзначаються запозичені постпозитивні форманти. Це вияв процесів глобалізації та інтелектуалізації в українському соціумі. Серед них найвищою інтенсивністю в сучасній українській мові характеризується афікс $-\boldsymbol{u c m} / \mathbf{i c m}$, що поєднується переважно з іншомовними та запозиченими основами (екологіст, рашист, алькаїдист, абсурдист, айкідойсm, кактусист 'людина, яка займається розведенням і колекціонуванням кактусів', візіаліст, бриджист, вікіпедист), рідше - із власне українськими (nорист 'прибічник або послідовник громадсько-політичної організації «Пора»). Аналізований суфікс сприяє продукуванню дериватів на позначення осіб чоловічої статі за родом діяльності, професією, а також прибічників, послідовників певних громадсько-політичних, релігійних, терористичних та ін. організацій, рухів, блоків тощо: На думку «пористів», сьогодні існує

19 «Слуга народу» 3 Черкащини втратив мову від привабливої панянки. Прочерк. 05.11.2019. Узято $3 \mathrm{https://procherk.info/news/7-cherkassy/76919-sluga-narodu-z-cherkaschini-}$ vtrativ-movu-vid-privablivoyi-panjanki.

20 Гринько О. Гостею цьогорічного BookForum стане авторка світового бестселера про Голокост. Zaxid.net. 30.07.2020. Узято з https://zaxid.net/gosteyu_tsogorichnogo_bookforum_stane_ avtorka_svitovogo_bestselera_pro_golokost_n1505723.

21 Тищенко Б. Як там прес-служба АТО пише, за минулу добу в зоні проведення... Прочерк. 07.02.2017. Узято $3 \mathrm{https://procherk.info/direct/448-tischenko/50057-tischenko-z-ukrayinoju-v-}$ sertsi.

22 На Львівщині сталась жахлива аварія. Кулеметсот. 20.06.2018. Узято з http://www. kulemet.com/na-lvivschyni-stalas-zhahlyva-avariya-foto-video-2/. 
загроза здобуткам помаранчевої револючї, пов 'язана з відсутністю у влади чіткої стратегіï реборм ${ }^{23}$.

Досить продуктивним у новітній період розвитку національної мови виступає запозичений афікс -amop, що приєднується переважно до чужомовних дієслівних твірних основ: глобалізатор, демократизатор ('той, хто проводить демократичні реформи, сприяє розвитку демократіі'), приватизатор, інтернаціоналізатор, консолідатор, мотиватор, глорифікатор, декларатор та ін., пор.: Серйозні поразки системи глобалізму в останній період, його іманентна криза змусила навіть головних глобалізаторів - лідерів країн G-8 заявити в 2000 році в Окінаві (Японія) 24 ; Дешам [головний тренер збірної Франції з футболу] заслужив повагу в тому, що він є прекрасним психологом і мотиватором ${ }^{25}$. В останні десятиліття поступово набуває активності й стає продуктивним давно запозичений суфікс -ap/-яр: хунтар ('член або прибічник хунти'), фільмар, санкар спорт. ('той, хто займається швидкісним спуском на спортивних санях'), зеленкар (розм. 'той, хто обливає зеленкою опозиційних політиків та публічних осіб'), попсар та ін. Пор.: Спонсорами німецьких санкарів і бобслеїстів $\epsilon$ німецькі автомобільні концерни (газ.«Високий замок», 13.02.2014.); Мілічія затримала аж чотирьох «зеленкарів», що облили Луценків ${ }^{26}$.

У досліджуваний період в українській мові, як засвідчує зібраний нами фактичний матеріал, порівняно з попередніми десятиліттями, помітно зросла продуктивність запозичених суфіксоїдів. 3-поміж останніх варто назвати: -ман, що вносить словотвірне значення 'особа чоловічої статі, яка має пристрасть або фанатичне ставлення до того, що виражено в першій частині слова' (телеман, ігроман, ребусоман, інтернетоман, машиноман, веломан, боксоман, дієтоман, джинсоман), -біл зі словотвірною семантикою 'великий любитель, пристрасний прихильник, фанатик, колекціонер кого-, чого-небудь' (натоффіл, зрадофіл, книгофіл, людинофіл, націєфіл, негрофіл), -фоб, що має значення 'той, хто боїться кого-, чого-небудь, не любить,

23 «Пористи» закликають нову владу визнати свої помилки. UV. 22.08.2005. Узято з https:// ukrainian.voanews.com/a/a-49-2005-08-22-voa3-87010967/226104.html.

24 Білорус О. Криза глобалізації та перспективи корпоративного глобалізму. Iнтернетхолдинг Олега Соскіна. Узято з http://soskin.info/ea/2003/1/20030103.html.

25 Адамович I. Свобода, рівність, братерство: як збірна Франції стала чемпіоном світу. Dynamo.kiev.ua. Узято 3 https://dynamo.kiev.ua/articles/304450-svoboda-rvnst-braterstvo-yakzbrna-frants-stala-chemponom-svtu.

26 Міліція затримала аж чотирьох «зеленкарів», що облили Луценків. Zaxid.net. 28.12.2013. https://zaxid.net/militsiya_zatrimala_azh_chotiroh_zelenkariv_shho_oblili_lutsenkiv_n1300098. 
$€$ противником або не терпить когось чи щось' (натофоб, телефбоб, кліпофоб, ісламофоб, банкофоб 'противник поширення банківської системи', трампобоб). Як бачимо, аналізовані інновації утворюються здебільшого на базі запозичених основ, хоч уже помітна тенденція до використання в ролі твірних питомих українських одиниць. Пор. у контексті: Кожен інтернетоман знаходить у мережі щось близьке для себе ${ }^{27}$; Провладні «натофіли» покладають великі надії на пропагандистську кампанію, яка ось-ось має нібито розпочатися ${ }^{28} ; 24$ роки в'язниці - в США оголосили вирок ісламофобу ${ }^{29}$. Малопродуктивними в процесі творення інновацій на позначення осіб виступають такі запозичені суфікси й суфіксоїди: -ант (правописант, експлуатант, nідnисант - розм. 'той, хто підписав відкритого листа, відозву і т. ін. до влади, політичних партій, рухів'), -їд (яндексоїд, гуглоїд), пор.: Мер Ужгорода став одним із підписантів звернення до влади щзоо неприпустимості змін до законодавства, щьо позбавить громади ресурсів ${ }^{30}$; Для обговорень яндексоїди, щоб не заважати колегам, збираються у переговорах ${ }^{31}$.

Непродуктивні суфікси й суфіксоїди не були предметом нашого аналізу.

\section{Висновки}

Отже, категорія назв осіб в українській мові початку XXI ст., як і лексична система загалом, динамічно розвивається й інтенсивно поповнюється новими словами. 3-поміж головних джерел оновлення і збагачення їі масиву найпродуктивнішим було й залишається суфіксальне словотворення. Засвідчено найбільш активне творення фемінних номенів. У перспективі варто глибше дослідити інші способи словотворення зазначених назв та основні тенденції в цих процесах як в українській, так і в сучасних слов’янських мовах.

27 Котова О. Інтернет - благо, що вбиває. Plus. 05.03.2010. Узято з https://plus.lviv.ua/ publ/13-1-0-49.

28 До проблеми українського нейтралітету. Zaxid.net. 28.08.2008. Узято з https://zaxid.net/ do_problemi_ukrayinskogo_neytralitetu_n1059796/amp.

2924 роки в'язниці - в США оголосили вирок ісламофобу. Іслам в Украні. https://islam. in.ua/ua/novyny-u-sviti/24-roky-vyaznyci-v-ssha-ogolosyly-vyrok-islamofobu.

30 Мер Ужгорода став одним із підписантів звернення до влади щодо неприпустимості змін до законодавства, що позбавить громади ресурсів. Закарпаття онлан. 30.03.2020. Узято 3 https://zakarpattya.net.ua/News/200845-Mer-Uzhhoroda-stav-odnym-iz-pidpysantiv-zvernenniado-vlady-shchodo-neprypustymosti-zmin-do-zakonodavstva-shcho-pozbavyt-hromady-resursiv.

31 Ділова Москва. Перекотиполе. 20.08.2016. Узято 3 https://perekotupole.wordpress. com/2016/08/20/moscow-calling/. 


\section{ЛІТЕРАТУРА}

1. Архангельська, А. (2019). Femina cognita. Украӥнська жінка у слові й словнику. Київ: Вид. дім Дмитра Бураго. 2. Буднікова, Л. Т. (2007). Назви осіб за професією у словацькій та українській мовах: словотвірний аспект. Наук. вісн. Ужгород. ун-ту, 16, 74-77. 3. Вишневська, Г. П. (2001). Функціонування агентивних іменників оцінної семантики в сучасній українській і російській мовах. Проблеми зіставної семантики, 5, 98-103. 4. Годована, М. П. (2007). Автохтонні та запозичені назви осіб за видом діяльності в українській мові. Украӥнська термінологія і сучасність, VII, 99-101. 5. Кислюк, Л. (2013). Жінка-космонавт чи космонавтка? (до проблеми норми назв осіб жіночої статі). Культура слова, 78, 114-118. 6. Кислюк, Л. (2017). Сучасна українська словотвірна номінація: ресурси й тенденції розвитку. Київ: Вид. дім Дмитра Бураго. 7. Навальна, М. I. (2011). Динаміка лексикону української періодики початку XXI cm. Київ: Ін-т укр. мови; Вид. дім Дмитра Бураго. 8. Навальна, М. I. (2008). Нові іменники зі значенням жіночої статі в мові української газетної публіцистики. Наук. вісн. Херсон. держ. ун-my, VII, 225-230. 9. Нелюба, А. М. (2011). «Гендерна лінгвістика» і малопродуктивні словотворчі засоби. Лінгвістика, 1 (22), 137-142. 10. Нелюба, А. М. (2011). Інноваційні зрушення й тенденції в українському жіночому словотворі. Лінгвістика, 2 (23), 49-59. 11. Ніколаєнко, Л. І. (1999). Структурно-семантична характеристика агентивів-композитів у польській мові. (Автореф. дис. ... канд. філол. наук). Київ: НАН України. Ін-т мовозн. ім. О. О. Потебні. 12. Сидоренко, Л. М. (2000). Дериватологія агентивів. Гуманітарний вісник, 4, 269-274. 13. Тараненко, О. О. (2015). Актуалізовані моделі в системі словотворення сучасної украйнської мови (кінець $X X$ - початок XXI cm.). Київ: Вид. дім Дмитра Бураго. 14. Тараненко, О. О. (2005). Принцип андроцентризму в системі мовних координат і сучасний гендерний рух. Мовознавство, 1, 3-25.

\section{REFERENCES}

1. Arkhanhelska, A. (2019). Femina cognita. Ukrainska zhinka u slovi y slovnyku [Feminine cognita. Ukrainian woman in word and dictionary]. Kyiv: Vyd. dim Dmytra Buraho [in Ukrainian]. 2. Budnikova, L. T. (2007). Nazvy osib za profesiieiu u slovatskii ta ukrainskii movakh: slovotvirnyi aspekt [Names of persons by profession in Slovak and Ukrainian languages: word-forming aspect]. Nauk. visn. Uzhhorod. un-tu - Scientific Bulletin of Uzhhorod University, 16, 74-77 [in Ukrainian]. 3. Vyshnevska, H. P. (2001). Funktsionuvannia ahentyvnykh imennykiv otsinnoi semantyky $\mathrm{v}$ suchasnii ukrainskii i rosiisjkii movakh [Functioning of agentive nouns of evaluative semantics in modern Ukrainian and Russian languages]. Problemy zistavnoi semantyky - Problems of comparative semantics, 5, 98-103 [in Ukrainian]. 4. Hodovana, M. P. (2007). Avtokhtonni ta zapozycheni nazvy osib za vydom diialnosti v ukraiinskii movi [Indigenous and borrowed names of persons by type of activity in the Ukrainian language]. Ukrainska terminolohiia i suchasnist - Ukrainian terminology and modernity, VII, 99-101 [in Ukrainian]. 5. Kysljuk, L. (2013). Zhinka-kosmonavt chy kosmonavtka? (do problemy normy nazv osib zhinochoi stati) [A woman astronaut or an astronaut? (to the problem of the norm of names of females)]. Kultura slova - The culture of the word, 78, 114-118 [in Ukrainian]. 6. Kysluk, L. (2017). Suchasna ukrainska slovotvirna nominatsiia: resursy y tendentsii rozvytku [Modern Ukrainian word-formation nomination: resources and development tendencies]. Kyiv: Vyd. dim Dmytra 
Buraho [in Ukrainian]. 7. Navalna, M. I. (2011). Dynamika leksykonu ukrainskoi periodyky pochatku XXI st. [Dynamics of the lexicon of Ukrainian periodicals of the beginning of the XXI century]. Kyiv: Instytut ukrainskoi movy; Vyd. dim Dmytra Buraho [in Ukrainian]. 8. Navalna, M. I. (2008). Novi imennyky zi znachenniam zhinochoi stati v movi ukrainskoi hazetnoi publitsystyky [New nouns with the meaning of female gender in the language of Ukrainian newspaper journalism]. Nauk. visn. Kherson. derzh. un-tu - Scientific Bulletin of Kherson State University, VII, 225-230 [in Ukrainian]. 9. Neliuba, A. M. (2011). «Henderna linhvistyka» i maloproduktyvni slovotvorchi zasoby [«Gender Linguistics» and unproductive word-formation tools]. Linhvistyka - Linguistics, 1 (22), 137-142 [in Ukrainian]. 10. Neliuba, A. M. (2011). Innovatsiini zrushennia y tendentsii v ukrainskomu zhinochomu slovotvori [Innovative shifts and trends in Ukrainian women's word formation]. Linhvistyka - Linguistics, 2 (23), 49-59 [in Ukrainian]. 11. Nikolaienko, L. I. (1999). Strukturno-semantychna kharakterystyka ahentyviv-kompozytiv u polskii movi [Structural and semantic characteristics of composite agents in the Polish language]. Extended abstract of candidate's thesis. Kyjiv: NAN Ukrajiny. In-t movoznav. im. O. O. Potebni [in Ukrainian]. 12. Sydorenko, L. M. (2000) Deryvatolohiia ahentyviv [Derivatology of agents]. Humanitarnyi visnyk - Humanitarian Bulletin, 4, 269-274 [in Ukrainian]. 13. Taranenko, O. O. (2015) Aktualizovani modeli v systemi slovotvorennia suchasnoi ukrainskoi movy (kinets XX - pochatok XXI st.) [Updated models in the word formation system of the modern Ukrainian language (end of the XX - beginning of the XXI century)]. Kyiv: Vyd. dim Dmytra Buraho [in Ukrainian]. 14. Taranenko, O. O. (2005) Pryntsyp androtsentryzmu v systemi movnykh koordynat i suchasnyi hendernyi rukh [The principle of androcentrism in the system of language coordinates and the modern gender movement]. Movoznavstvo - Lingvistics, 1, 3-25 [in Ukrainian].

Стишов Олександр Анатолійович - доктор філологічних наук, професор, професор кафедри української мови, Київський університет імені Бориса Грінченка; вул. Драгоманова, буд. 22, кв. 114, Київ 02068, Україна.

Tel.: +38-067-184-80-55, дом. (044) 570-25-99

E-mail: styshov@ukr.net

https://orcid.org/0000-0001-6192-255X

Styshov Oleksandr Anatoliiovych - Doctor of Philological Sciences, Professor, Professor of the Department of Ukrainian Language, Borys Grinchenko Kyiv University; Drahomanov Str., 22, ap. 114, Kyiv, 02068, Ukraine.

Надійшла до редакції 25 вересня 2020 року

\section{CITATION}

ДСТУ 8302:2015: Стишов О. А. Особливості суфіксального словотворення неологізмів на позначення осіб у сучасній українській мові. Лінгвістичні дослідження: зб. наук. пр. Харк. нац. пед. ун-ту імені Г. С. Сковороди. Харків, 2020. Вип. 53. С. 127-140. DOI: https://doi.org/10.34142/23127546.2020.53.12

APA: Стишов, О. А. (2020). Особливості суфіксального словотворення неологізмів на позначення осіб у сучасній українській мові. Лінгвістичні дослідження, 53, 127-140. DOI: https://doi.org/10.34142/23127546.2020.53.12 